\title{
Evaluation of anticonvulsant activity of ACE inhibitors (imidapril and quinapril) in experimentally induced animal models of epilepsy
}

\author{
Pushpa VH*, Poornima R., Kalabharathi HL, Satish AM
}

\author{
Department of Pharmacology, \\ JSS Medical College, JSS \\ University, Mysore, India \\ Received: 25 February 2016 \\ Accepted: 21 March 2016

\section{*Correspondence to: \\ Dr. Pushpa VH, \\ Email: drpushpasatish \\ @gmail.com}

Copyright: () the author(s), publisher and licensee Medip Academy. This is an openaccess article distributed under the terms of the Creative Commons Attribution NonCommercial License, which permits unrestricted noncommercial use, distribution, and reproduction in any medium, provided the original work is properly cited.

\begin{abstract}
Background: Epilepsy is a chronic neurological disorder characterized by an enduring predisposition to generate seizures, may be associated with emotional and cognitive dysfunction. Objective of this study was to evaluate and compare the anticonvulsant activity of different doses of imidapril and quinapril in animal models of epilepsy.

Methods: Swiss albino mice weighing around 25-30g of either sex were divided into 6 groups: control (R.O-10 ml/kg), standard-sodium valproate (40 $\mathrm{mg} / \mathrm{kg}$ ), Q1-quinapril (1.5 mg/kg), Q2-quinapril (10.4 mg/kg), I1-imidapril $(0.65 \mathrm{mg} / \mathrm{kg})$ and I2-imidapril $(2.6 \mathrm{mg} / \mathrm{kg}) .1$ hour after administration of control, test and standard drugs (orally) test was conducted. Convulsions were induced by administering PTZ (70 mg/kg-i.p.) in PTZ model. Seizure latency was the parameter recorded. In MES model, maximal seizures were evoked by supra maximal electroshock stimulation of $50 \mathrm{~mA}, 50 \mathrm{HZ}$ for 0.2 seconds by using conventional electro convulsion meter. Suppression of tonic hind limb extension was taken as measure of efficacy.

Results: The results were analysed by one-way-ANOVA followed by Bonferroni's multiple comparison test. In MES test, dose dependently quinapril and imidapril significantly reduced the duration of tonic hind limb extension in comparison to control $(\mathrm{p}<0.05)$ percentage inhibition of seizures by $\mathrm{I} 2$ is $58.1 \%$, I1-38.6\%, Q2-19.7\% and Q1-12.2\% with maximum inhibition of seizure produced by $\mathrm{I} 2$ in comparison to control in MES test. In PTZ test, dose dependently quinapril and imidapril produced significant increase in seizure latency $(\mathrm{p}<0.05)$. Percentage inhibition of seizures by I2-65.8\%, I1-59.3\%, Q2$50.9 \%$ and Q1-33.5\% in comparison to control.

Conclusions: Quinapril and imidapril in a dose dependent manner showed increase in antiepileptic activity, imidapril has better antiepileptic activity when compared to quinapril.
\end{abstract}

Keywords: Antiepileptic activity, ACE inhibitor, MES model, PTZ model, Quinapril, Imidapril

\section{INTRODUCTION}

Epilepsy is a chronic neurological disorder characterized by an enduring predisposition to generate seizures, may be associated with emotional and cognitive dysfunction. ${ }^{1}$ This disorder affects 50 million people worldwide and hence, is one of the most common neurological disorder. Despite the availability of a wide range of antiepileptic drugs (AEDs), about one-third of individuals with epilepsy still experience seizures that do not respond to medication. ${ }^{2}$ Thus, an urgent need exist for effective therapies to be developed. In spite of the vast number of drugs introduced for the treatment of epilepsy, there is still a need for an ideal antiepileptic agent with broad spectrum of activity, rapid onset of action, more economical and least side effects.

Epilepsy may be associated with other comorbid conditions like hypertension, diabetes, renal disorders etc. Many researches are in progress, to prove if the drugs used for these disorders like ACE inhibitors, calcium channel blockers, AT II receptor antagonist etc. have any effect on seizure prevention. 
Brain has its own intrinsic renin angiotensin system, which has been implicated in functions including regulation of cerebral blood flow, cerebro protection, stress, depression, seizure, nociception and other neurological and psychiatric disorders. ${ }^{3}$ A detailed analysis of the RAS can be carried out in part through the study of the enzymes, named angiotensinases, involved in its cascade, whose activity is a reflection of the functionality of their peptide substrates. The study of these enzymes offers the possibility of controlling the effects of angiotensin's through various pharmacological manipulations. For example, angiotensinase inhibitors or activators are being used or have been proposed as antihypertensive agents. They have also been suggested as analgesic and antidepressant drugs or targets for drug development against different pathologies such as Alzheimer's disease, epilepsy or ischemia. ${ }^{4}$ Angiotensin II has neurotransmitter role in CNS as well as it regulates other neurotransmitters such as GABA, NA, 5-HT, Ach release etc. ${ }^{5}$ It inhibits GABAergic synaptic transmission in dorsolateral periaqueductal gray neurons through activation of presynaptic AT1 receptors. ${ }^{6}$ Hence, ACE inhibitors and AT1 receptor antagonists can facilitate GABAergic transmission which is useful in seizure prevention.

Research on captopril, fosinopril and zofenopril and their effect on seizures have been studied which show favourable results and all the drugs have an additive anticonvulsant effect when co administered with other conventional antiepileptic drugs. ${ }^{7}$

With studies suggesting role of AT 1 receptors and angiotensinase in seizure regulation and presence of renin angiotensin system in brain is involved in the regulation of seizure susceptibility, the present study was undertaken to study and compare the effect of ACE inhibitors (imidapril and quinapril) in animal models of epilepsy.

\section{METHODS}

Albino mice of either sex weighing 25-30 gms aged 3-4 months were bred in central animal house. They were housed in groups of three in clean polypropylene cages with 12 hours light/dark cycle at $25 \pm 2{ }^{\circ} \mathrm{C}$ and $65 \pm 5 \%$ humidity. They had access to food (standard pellet diet, Hindustan lever ltd.) and water. All experiments were carried out between 11 am and $3 \mathrm{pm}$. The ethical clearance was obtained from the institutional animal's ethical committee.

R.O water (control group), standard drug valproic acid (40 mg/kg) and test drugs Q1-quinapril (1.5 mg/kg), Q2quinapril $(10.4 \mathrm{mg} / \mathrm{kg})$, I1-imidapril $(0.65 \mathrm{mg} / \mathrm{kg})$ and $\mathrm{I} 2$ imidapril $(2.6 \mathrm{mg} / \mathrm{kg})$ were administered orally 1 hour prior to MES and PTZ tests.

\section{Evaluation of antiepileptic activity}

\section{Maximal electroshock induced seizure}

Electrical stimulation was applied via ear electrodes with a current strength of $50 \mathrm{~mA}$ for $0.2 \mathrm{sec}$. The resultant seizure passed through various phases; phase of tonic limb flexion, phase of tonic limb extension, followed by variable short clonic interval. 24 hours before testing of anticonvulsants (to avoid any possible kindling effect), the animals were pre-screened for their ability to develop full tonic extension in the maximal electroshock test. Suppression of tonic hind limb extension was taken as measure of efficacy in this test.

\section{Pentylenetetrazole (PTZ) induced convulsion}

1 hour after oral administration of test and standard drugs, $70 \mathrm{mg} / \mathrm{kg}$ pentylenetetrazole was injected intra puritanically. Each animal was placed into an individual plastic cage for observation lasting 30 minutes. Within 30 minutes they developed a sequence of excitement, myoclonic jerks, clonic seizures, one or more maximal tonic seizures followed by recovery. Seizure latency and abolition of clonic seizures with loss of righting reflex was taken as index of protection.

\section{Statistical analysis}

The effect of quinapril and imidapril in different doses in MES and PTZ models of seizure induction were expressed as mean \pm SD . Percentage inhibition of seizure was calculated respectively. Data was analysed using one-way ANOVA followed by Bonferroni's multiple comparison tests. $\mathrm{P}$ values $<0.05$ were considered significant.

\section{RESULTS}

Table 1: Effect of quinapril and imidapril in different doses on duration of tonic hind limb extension in MES model.

\begin{tabular}{|lll|}
\hline Groups & \multicolumn{1}{|c|}{$\begin{array}{l}\text { Duration of tonic } \\
\text { hind limb extension } \\
\text { (seconds) }\end{array}$} & $\begin{array}{l}\text { Clonus } \\
\text { (seconds) }\end{array}$ \\
\hline $\begin{array}{l}\text { Control R.O water }(10 \\
\mathrm{ml} / \mathrm{kg})\end{array}$ & $16.83+1.47$ & $10.5+1.05$ \\
\hline $\begin{array}{l}\text { Standard valproic acid (40 } \\
\mathrm{mg} / \mathrm{kg})\end{array}$ & $5.83+0.64$ & $2.67+0.82$ \\
\hline Q1 Quinapril $(1.5 \mathrm{mg} / \mathrm{kg})$ & $14.83+1.16$ & $5+2.14$ \\
\hline Q2 Quinapril $(10.4 \mathrm{mg} / \mathrm{kg})$ & $13.5+1.04$ & $4+1.10$ \\
\hline I 1 Imidapril $(0.65 \mathrm{mg} / \mathrm{kg})$ & $10+2.69$ & $3+5.16$ \\
\hline I2 Imidapril $(2.6 \mathrm{mg} / \mathrm{kg})$ & $7.33+3.27$ & $1.33+3.27$ \\
\hline
\end{tabular}

Values are expressed as mean + SD. Statistical analysis of data was carried out by one way ANOVA. ${ }^{*} p<0.05$ is considered significant 


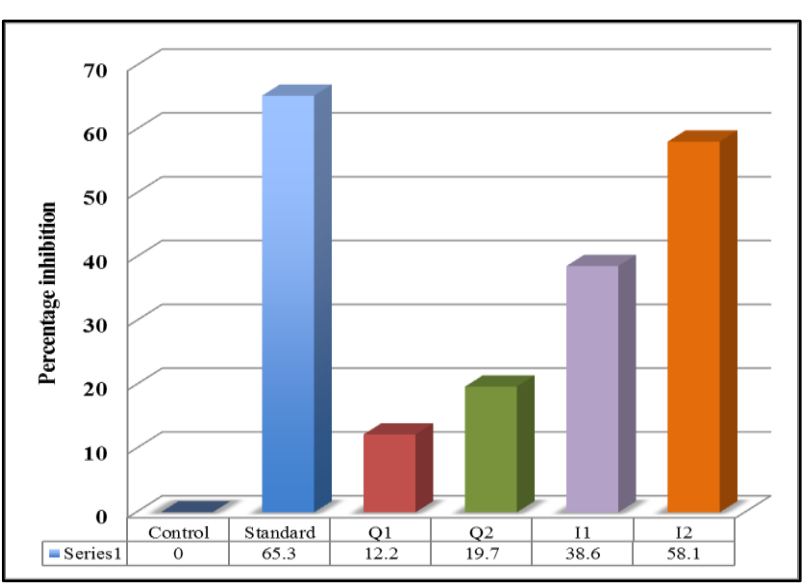

Figure 1: Percentage protection rendered against seizure by quinapril and imidapril in MES model in comparison to control.

Table 2: Duration of seizure latency and generalized seizures.

\begin{tabular}{|llc|}
\hline Groups & $\begin{array}{l}\text { Seizure } \\
\text { latency } \\
\text { (seconds) }\end{array}$ & \multicolumn{2}{c|}{$\begin{array}{l}\text { Generalised } \\
\text { seizures with loss } \\
\text { of righting reflex }\end{array}$} \\
\hline $\begin{array}{l}\text { Control R.O water } \\
\text { (10 ml/kg) }\end{array}$ & $146.67+1.67$ & $15.5+0.8$ \\
\hline $\begin{array}{l}\text { Standard Valproic } \\
\text { acid (40 mg/kg) }\end{array}$ & $353+2.82$ & $3+1.09$ \\
\hline $\begin{array}{l}\text { Q1 Quinapril } \\
\text { (1.5 mg/kg) }\end{array}$ & $157.16+4.4$ & $10.3+2.05$ \\
\hline $\begin{array}{l}\text { Q2 Quinapril } \\
\text { (10.4 mg/kg) }\end{array}$ & $175+2.69$ & $7.6+1.67$ \\
\hline $\begin{array}{l}\text { I1 Imidapril } \\
\text { (0.65 mg/kg) }\end{array}$ & $238.33+8.06$ & $6.3+0.95$ \\
\hline $\begin{array}{l}\text { I2 Imidapril } \\
\text { (2.6 mg/kg) }\end{array}$ & $298.33+5.43$ & $5.3+1.39$ \\
\hline
\end{tabular}

Values are expressed as mean+SD. Statistical analysis of data was carried out by one-way ANOVA. *p $<0.05$ is considered significant.

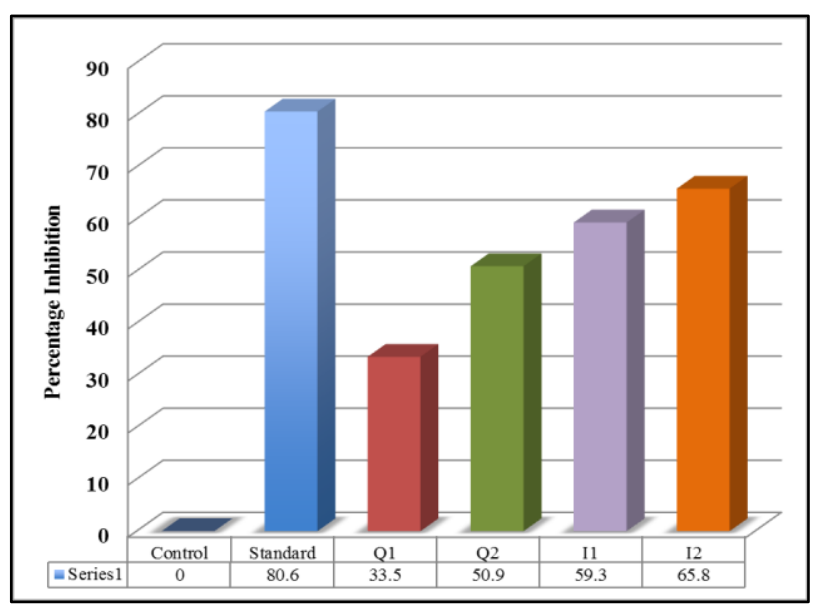

Figure 2: Effect of quinapril and imidapril on duration of seizure latency in PTZ model.

\section{Maximum electroshock induced seizures}

Quinapril and imidapril produced significant antiepileptic activity in comparison to control. Duration of tonic hind limb extension in MES test is shown in (Table 1). All the animals recovered from the MES induced seizure. The percentage protection rendered is shown in (Figure 1).

\section{PTZ induced seizures}

In PTZ model, seizure latency by two different doses of quinapril and imidapril is significantly increased in comparison to control group as shown in (Table 2). I2 significantly increased seizure latency to $298.3+5.43$ when compared to I1, Q1 and Q2. Percentage inhibition of seizure is shown in (Figure 2).

\section{DISCUSSION}

Epilepsy is a group of heterogeneous neurological disorder characterized by spontaneous and recurrent seizures and is one of the most common health disorders that affect $1 \%$ of the population. The anticonvulsant therapy available is neither universally effective nor invariably safe. Compliance with medication is a major problem because of the need for long-term therapy together with unwanted effects of many drugs. In the recent years a wide variety of targets have been identified and studied and brain renin angiotensin system is an important one .In the above study, both quinapril and imidapril dose dependently suppressed the duration of hind limb extension in MES model. Imidapril at dose of $2.6 \mathrm{mg} / \mathrm{kg}$ significantly reduced this parameter in comparison to control, Q1, Q2 and I1. Percentage inhibition of seizure by I2 is $58.1 \%$, I1 - 38.6\%, Q2$19.7 \%$ and Q1-12.2\% with maximum inhibition of seizure produced by I2. In PTZ test, percentage inhibition of seizure by $\mathrm{I} 2-65.8 \%, \mathrm{I} 1-59.3 \%, \mathrm{Q} 2-50.9 \%$ and Q1-33.5\% in comparison to control. This shows that 12 produced significant inhibition of seizure. This study suggests that antiepileptic activity of ACE inhibitors is dose dependent. imidapril has a better efficacy compared to quinapril.

The brain renin angiotensin system plays an important role in the regulation of neurogenic hypertension, cerebrovascular fluid homeostasis and sodium intake, stroke, epilepsy, Alzheimer's disease, Parkinson's disease, depression and stress disorders. Renin angiotensin system (RAS) has a crucial role in the regulation of neurological functions by modulating glutamate/GABA release in the brain. ${ }^{8}$ In a rat model of epilepsy, it was found that components of the RAS, namely ACE and the AT1 receptors are up-regulated in the brain following repetitive seizures. ${ }^{9}$ Angiotensin has also been shown to modulate the voltage dependent delayed rectifier potassium current (IK) and IA. ${ }^{10}$

Reports suggest higher incidence of seizures in presence of pre-existing chronic inflammatory disorders. Many neurotransmitters like GABA, NA, acetyl choline as well 
as neuropeptides are influenced by cytokines. Induction of spontaneously recurring seizure involves activation of inflammatory cytokines and related pro and antiinflammatory gene in hippocampus. Angiotensin II is involved in regulating cytokines. ACE inhibitors may provide protection from seizures invoked by these cytokines. ${ }^{11}$ These are the various mechanisms through which angiotensin II and angiotensinase is involved in seizure generation and hence ACE inhibitors can be used in treatment of epilepsy.

\section{CONCLUSION}

Renin angiotensin system forms a newer target in treatment of epilepsy. ACE inhibitors produced significant antiepileptic activity which is dose dependent. imidapril has better antiepileptic activity when compared to quinapril. However further studies needs to be done to determine their exact mechanism of action and their efficacy as an adjuvant drug.

Funding: No funding sources

Conflict of interest: None declared

Ethical approval: The study was approved by the Institutional Ethics Committee

\section{REFERENCES}

1. Duncan JS, Sander JW, Sisodiya SM, Walker MC. Adult epilepsy. Lancet. 2006;367:1087-100.

2. Perucca E, French J, Bialer M. Development of new antiepileptic drugs: challenges, incentives, and recent advances. Lancet Neurol. 2007;6:793-804.

3. Pandy V, Subash H, Jose N. Depression like effects of telmisartan in mice forced swim test: involvement of brain monoaminergic system. Journal of Pharmacology and Toxicology. 2012;7(2):87-95.

4. Ramírez-Sánchez M, Prieto I, Wangensteen R, Banegas I, Segarra AB, Villarejo AB, et al. The renin-angiotensin system: new insight into old therapies. Curr Med Chem. 2013;20(10):1313-22.

5. Hosseini M, Alaei H, Sharifi MR, Shafeia MS. The effects of angiotensin II and captopril on expression of morphine withdrawal signs in rats. IJPR. 2007;6(3):185-91.

6. Xing J, Lu J, Li J. Angiotensin II inhibits GABAergic synaptic transmission in dorsolateral periaqueductal gray neurons. Neurosci Lett. 2009;455(1):8-13.

7. Sarro GD, Paola ED, Gratteri S, Gareri P, Rispoli V, Siniscalchi A, et al. Fosinopril and zofenopril, two angiotensin-converting enzyme (ACE) inhibitors, potentiate the anticonvulsant activity of antiepileptic drugs against audiogenic seizures in DBA/2 mice. Pharmacol Res. 2012;65(3):285-96.

8. Tsuda K. Renin-angiotensin system and sympathetic neurotransmitter release in the central nervous system of hypertension. International Journal of Hypertension. 2012;2012:1-11.

9. Pereira MG. Inhibition of the renin-angiotensin system prevents seizures in a rat model of epilepsy. Clin Sci (Lond). 2010;119(11):477-82.

10. Latchford KJ. Electrophysiological effects of angiotensin II on hypothalamic para ventricular nucleus neurons of the rat; 2008. Available at http://qspace.library.queensu.ca/bitstream/1974/995/1 /Latchford_Kevin_J_200801_PhD.pdf.

11. Rao RS, Prakash A, Medhi B. Role of different cytokines and seizure susceptibility. A new dimension towards epilepsy research. Indian journal of experimental biology. 2009;47:625-34.

Cite this article as: Pushpa VH, Poornima R, Kalabharathi HL, Satish AM. Evaluation of anticonvulsant activity of ACE inhibitors (imidapril and quinapril) in experimentally induced animal models of epilepsy. Int J Basic Clin Pharmacol 2016;5:798-801. 